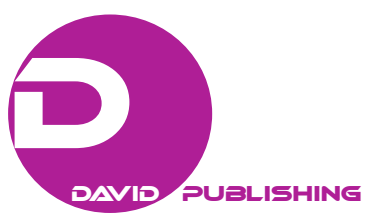

\title{
China’s Military Build-up and India’s Response
}

\author{
Jaebeom Kwon \\ University of Nebraska-Lincoln, Lincoln, USA
}

\begin{abstract}
Since the 1990s, the rise of China has become realized. China has shown dramatic economic, and expanded its political influences at both regional and international levels. More importantly, it has accelerated its military build-up since the 1990s, and widened a gap between military capabilities of China and those of neighboring countries. In response to China's strengthening military power and capability, India, one of the most potential competitors for regional hegemony, is at a crossroads. How has India perceived China's remarkable military build-up? And, based on India's perception, how has it responded? This article argues that, relying on the logic of neorealism, India has seen China's military build-up as a significant threat to its national interest and security. After exploring India's strategies in response to China's strengthening military power, empirical analysis reveals that, facing a threat from China's growing military power, India's response could be characterized as internal and external balancing against China.
\end{abstract}

Keywords: Sino-India relations, balancing strategy, China's military build-up

\section{Introduction}

The world has witnessed the rise of China, and this rise is a key factor that leads to the shift in the distribution of power in Asia. China has shown dramatic economic development since the 1980s. For instance, its average real growth has increased by more than nine percent annually during the last 30 years, exceeding the other remarkable economic growth of the four Asian tigers, and its per capita income has risen by more than six percent every year from 1978 to 2003 (Tellis, 2011, p. 3). Moreover, China has accelerated and strengthened its military capability, and obtained predominant military power, compared to its neighboring countries. Based on this accumulated economic and military power, China has been expanding its political leverage on the international scene, and redefining and promoting its so-called "core interests". Therefore, with the relative decline of US influence in the region and of Japan's economic power, China has become the most important player in the balance of power in Asia.

At the same time, the rise of India, which has been considered another potential regional hegemon, is also a very significant variable in understanding the regional order in Asia. As China's most formidable regional competitor, India also has achieved outstanding economic development since the early 1990s, and has grown its economy by $7.5 \%$ in the 2000 s, doubling its per capita income (Tellis, 2011, p. 4). In terms of military development, India has made significant efforts to modernize its military force, specifically focusing on its naval force, and, as a result, it has enhanced its defense and projection capability.

With their remarkable economic and military growth, both China and India also have strong self-confidence on the international scene. At the international level, for instance, China expresses its strong

Jaebeom Kwon, Ph.D. student, Department of Political Science, University of Nebraska-Lincoln. 
opinion about certain issues, sometimes opposing the United States (the US) in the United Nations Security Council. India is making active efforts to become a permanent member of the Security Council. At the regional level, moreover, both countries have expanded their economic and military leverage on their neighboring countries with their economic resources, and played a leading role in establishing various regional organizations.

Based on this current phenomenon in Asia, the author proposes the following questions: how has India, one of the rising powers in Asia, perceived the rise of China, which already has been the regional hegemon? In addition, based on India's perspective on the rise of China in general, and China's military build-up in particular, how has India responded?

This topic is essential for the following reason. Since a shift in the balance of power among Asian countries could have direct impacts on the regional order, understanding the power distribution between these two regional hegemons is significant. Their behaviors also influence the actions of other countries in the world, such as the US and other Asian countries. In other words, if India perceives the rise of China as a significant threat against its national interests, and therefore pursues a balance of power strategy against China, on the one hand, the regional order in Asia is likely to be much more competitive than cooperative. On the other hand, if India sees the rise of China as an opportunity for its further economic development, and decides to cooperate with China, Asian countries including these two are likely to enjoy more cooperative and favorable relationship. Moreover, given that both China and India have forged close ties with other regional countries in various arenas, as a result many regional actors have come to rely on these two countries, either China's or India's policy toward the other could have significant influences on other regional countries' policies.

In the following sections, the author firstly deals with a theoretical framework, specifically a neorealist perspective. Although this school does not specifically explain the Sino-Indian relationship, it provides a useful analytic framework for understanding how both countries see each other's rise and their respective likely policy options. Then, the author explores the current state of China's military build-up, and compares China's military power to India's to show that the former's military strength overpowers the latter's. Then, throughout a neorealist lens, India's perspective on China's military build-up, and its internal and external balancing strategy will be dealt with, followed by the conclusion.

\section{Theoretical Framework: A Neorealist Perspective}

Neorealism has a pessimistic perspective on international cooperation among countries. Under anarchical order, in which there is no central authority that can govern states' behaviors on the international scene, states should act for their own self-help (Waltz, 1979, p. 118). However, one country's self-help behavior could be considered a threat by other countries, because no country can know others' intentions, which causes security dilemma situation. Under this security dilemma, if one country's national power becomes stronger than that of other countries, the other countries may think that they could be threatened or even attacked by the powerful country in the future, and therefore, these other countries try to maintain balance of power structure, by implementing internal (e.g., strengthening economic and military power) and external balancing behavior (e.g., alliances). After all, Waltz (1979) considered shift of power distribution as the most significant factor in explaining international politics, and suggested that, when facing one country's expansion of national power, maintaining balance of power is the most effective and practical way for other countries' survival, stating that "if there is any distinctively political theory of international politics, balance-of-power theory is it" (p. 117). 
If applying Waltz's logic to the current situation related to China and India, there are various factors that support Waltz's logic of neorealism, even though China and India have established close economic relationship for a decade. In other words, the rise of China has caused significant shift of power distribution among Asian countries, specifically after the Cold War ended. And then, China's rise and its recent behavior cause India to have deep-rooted distrust against China, perceive the rise of China as threatening, and carry out balancing behavior. For example, based on its strengthened economic and military power, China is strengthening its military activities around India's important area-border area and the Indian Ocean region-and making further closer relationship with other regional countries, some of which have long history of antagonism with India (i.e., Pakistan and Bangladesh). Indeed, these behaviors that China has recently carried out could be considered a significant threat to India' national security, because these could constrain India's strategic options and have direct impact on India's national security. And eventually, the practical strategic policy that India has implemented to deal with the rise of China is characterized as a balancing behavior against China. In other words, facing China's increased military threat and the widening gap between these two countries' national powers, India cannot help but undertake various balancing strategic policies, both internally (India's military modernization and pursuit of nuclear weapons program and intercontinental ballistic missile program) and externally (India's establishment of bilateral relationship with other regional actors) in order to stabilize its national security.

However, one may argue that change of power distribution, specifically one country's increasing power, does not necessarily cause other weak countries' balancing strategy. In terms of this argument, another variant of Kenneth Waltz' defensive realism, balance of threat theory by Stephen Walt (1987) provides a useful analytical framework to understand the Sino-India relationship and India's strategic behavior. Not solely relying on the relative distribution of power, Stephen Walt stresses the necessity of considering whether a rising country is threatening or not. According to him, threat consists of a rising country's aggregate power, offensive power, geographical proximity, and aggressive intention, and if weak countries consider the rising country as a significant threat, they take a balancing behavior, namely alliance (Walt, 1987). Considering that China shares long border line with India, that China recently has taken more aggressive actions toward some border issues, and that it has enhanced its power projection capabilities, there are many reasons why India considers a rising China as a threat. That is to say, Stephen Walt's balance of threat theory still explains well why India currently shows enthusiastic aspirations for establishing close bilateral relationship with the US, ASEAN countries, Japan, and South Korea. After all, both Kenneth Waltz's defensive realism and Stephen Walt's balance of threat theory may argue that the rise of China could be perceived as a threatening factor by India, and India's useful strategy is a balancing behavior against China.

In sum, even though China has tried to rhetorically show that its rise is peaceful and that it does not have any aggressive intentions, China's economic and military growth naturally leads its neighboring countries, specifically India which has a deep-rooted distrust of China and competes with China over various sectors around the world, to doubt China's real intentions and to feel national security concerns. Uncertainty has existed for decades in Asia and between China and India, and as China's national power increases, both uncertainty and India's security concerns may increase as well. Eventually, India's most substantive and effective strategy to respond to China's rise could be, according to Waltz, to adopt balancing policy against China. 


\section{Research Method}

To find an answer to research questions, the author compares India's military build-up, nuclear weapons program, and bilateral relationship with other regional countries, before the rise of China (between the 1970s and 1980s), and after the rise of China (between the 1990s and 2000s). As an additional explanation, the author argues that the rise of China began in the early 1990s for two reasons. First, even though China enforced its openness and reform policy during the 1970s, its dramatic economic growth has appeared since the 1990s, and its military budget also drastically increased during the same period. This implies that the rise of China began in earnest in the 1990s, and did not appear until the late 1980s. Second, the fact that the Cold War ended around the early 1990s is taken into consideration. In other words, even though China was a strong regional power during the Cold War era, it was also controlled by bipolar system during that time, and may not have been regarded as an insurmountable threat to India, which had close relationship with the Soviet Union. However, after the Cold War ended, and the security guarantee from the Soviet Union vanished, China's full-fledged and fast-growing rise may have come as a greater shock to India. That is to say, the rise of China since the 1990s has actually shifted the distribution of power in Asia and, widened the gap of power between China and India, which may have led India to carry out its balancing policies against China since the 1990s. By comparing these two eras, the author has observed that there are some degrees of differences between India's military build-up, its pursuit of nuclear weapons program, and foreign policy during the Cold War era (the 1970s and 1980s), and after the 1990s.

\section{The Rise of China: China's Military Build-up}

A country's development of its national strength is one the most important factors that could have an impact on the regional order in Asia. Currently, the most remarkable change in national power is China's rise. In this regard, there are neorealist explanations of why China has engaged in its efforts to strengthen its power. Most of all, China's current bids for increasing its power could be motivated by its concern about fundamental survival under anarchy. That is to say, China's rise could be interpreted as its own counterbalancing against the US. In other words, the US has been the most powerful country since the Cold War ended, and is expanding its political, economic, and military influences on the whole world, including Asia. Moreover, the US has recognized China as the keenest competitor on the international scene, since the Soviet Union broke down. In order to maintain its position in Asia, the US has subsequently taken various containment measures designed to tackle a rising China, by forming close relationship with various Asian countries. Facing this situation, China may perceive that the US is trying to restrain it, and is concerned about its national security. Therefore, China may make active bids to strengthen its national power. In addition, China's rise also could be understood as its bid to be a regional hegemon. According to Mearsheimer (2001), countries are always concerned about their survival under anarchy, and they should maximize their own power in order to stabilize their survival. That is to say, the most effective way for countries to guarantee their survival is to obtain greater power than other countries, and therefore, to hold a hegemonic position. However, since there is a key limitation connected to geography and military projection capability, a realistic goal for countries should not be to become the world hegemon, but a regional one (Mearsheimer, 2001, pp. 140-141). In this regard, China may try to become a regional hegemon, by maximizing its national power to stabilize its security.

Consequently, China has shown its remarkable rise and, this dramatic military growth of China is proved 
by various indicators, such as national defense expenditure. When compared to other Asian countries, China's relative military power is noticeable. In terms of China's national defense spending, China overpowers other Asian countries, and has become the second-largest military power after the US (Tellis \& Tanner, 2012, p. 386). After all, China's military development has become the most significant factor in the shift of balance of power structure in Asia, and therefore, in order to understand other regional countries' responses, including India's, as well as the regional order, it is necessary to research China's military growth in detail. In this part, thus, the author will deal with China's military development in detail, using various indicators, and then, analyzes implications of China's rise to India.

\section{China's Military Growth}

China has increased its national defense budget, particularly since the early 1990s, and its military expenditure has shown a steep upward trend during the last two decades. Eventually, the amount of China's defense budget has become the second largest in the world, after only the US (see Table 1). Moreover, as China has increased its military expenditure, it also has increased its budgets to purchase arms from foreign countries, making it the world's leading arms importer since the mid 1990s (Gilboy \& Heginbotham, 2012, p. 167).

Table 1

Asian Countries' Military Expenditure (Million Dollars)

\begin{tabular}{|c|c|c|c|c|c|c|c|}
\hline & 1989 & 1990 & 1995 & 2000 & 2005 & 2010 & 2014 \\
\hline China & 18263 & 19735 & 22992 & 36995 & 71425 & 136220 & 190974 \\
\hline India & 19093 & 18807 & 19610 & 27653 & 36053 & 49158 & 49999 \\
\hline USA & 551766 & 527097 & 411631 & 394097 & 579768 & 720220 & 577511 \\
\hline Japan & 46585 & 47810 & 56827 & 60284 & 61288 & 59003 & 59033 \\
\hline South Korea & 14544 & 15076 & 19344 & 20036 & 24722 & 29912 & 33142 \\
\hline Taiwan & 10811 & 11406 & 12314 & 10384 & 9413 & 9904 & 10135 \\
\hline
\end{tabular}

Source. SIPRI military expenditure database.

Notes. Figures are in US dollars, at constant 2011 prices and exchange rates, except for the last figure of 2014 prices and exchange rates.

With its noticeably increased national defense expenditure, China has been committed to modernizing its military capability, mainly focusing on its naval modernization. For example, China's People's Liberation Army Navy (PLAN) has produced various types of the state-of-the-art nuclear-powered submarines (Erickson, 2012, pp. 67-68). As a result of China's active efforts to develop its indigenous submarines as well as acquire foreign ones, the current capability of Chinese submarines has become comparable to that of the US. According to Cole (2010), "except for submarines, China remains far behind the United States in terms of fleet modernization" (p. 87), and this implies that, at least in terms of submarines, China's ability does not remain behind the US. Furthermore, China recently has expressed its ambition and interest in acquiring aircraft carriers, and as a result, China's first aircraft carrier, the former Soviet Varyag, a 53,000-ton Kuznetsov-class, began sea trials in 2011, with the aim of achieving operational capability in 2015 (Erickson, 2012, p. 73; Gilboy \& Heginbotham, 2012, p. 176). Not surprisingly, China currently plans to allocate its future aircraft carriers to the South Sea Fleet (Rahman \& Tsamenyi, 2010, p. 324). This study argues that China is doing this to strengthen PLA Navy's projection capability and to widen its operation radius from the South China Sea to the Indian Ocean and Eastern part of Africa. In addition, the PLA Navy has taken significant steps to develop various 
cutting-edge surface combatants, all of which empower China to conduct 21 st century multi-mission tasks in the sea (Cole, 2010, pp. 97-108). Eventually, it is thought that, as a result of China's naval modernization, China has acquired the third-strongest naval power in the world in both qualitative and quantitative terms, behind only the US, and Russia (Pant, 2009, p. 287).

In addition to naval modernization, China's PLA Air Force (PLAAF) also has carried out its modernization processes. It has acquired a significant number advanced aircrafts, components, and aero-engines from Russia, and has produced its indigenous fourth-generation fighters (Erickson, 2012, pp. 70-71). Moreover, China has developed long-range conventional precision strike system that could have global reach by 2025, and established 13 more launch brigades (Stokes, 2012, p. 136). All of these military build-up allow China to establish superiority over all of the Asian-Pacific countries, and therefore, to have more strategic and military options with regard to territorial disputes with its neighboring countries.

Specifically, compared to India, there is a growing gap between these two countries' military power. As Table 2 indicates, China has much larger number of conventional warfare weapons as well as nuclear warheads than India, and therefore, China enjoys relative predominance over India, in terms of quantity of weapons.

Table 2

The Number of China's and India's Weapons

\begin{tabular}{lllllr}
\hline & Thanks, APCs / LAVs, Artillery & Fixed-wing aircraft & Principal surface combatants & Submarines Nuclear Warheads \\
\hline China & 29,680 & 2,600 & 63 & 69 & 410 \\
India & 12,874 & 714 & 25 & 16 & $70-110$ \\
\hline
\end{tabular}

Source. Tellis \& Wills, 2005, pp. 441-442.

Notes. Data of nuclear warheads is from 2004, and others from 2003.

In addition, China has more advanced ability to produce indigenous aircraft, and has more state-of-the-art aircraft, such as fourth-generation fighters, and larger bomber force than India (Gilboy \& Heginbotham, 2012, p. 190). Furthermore, as mentioned above, China has the third greatest naval power in the world, and this indicates that Chinese navy already holds a dominant position over Indian navy. Moreover, China's nuclear weapons and delivery system are superior to India's in terms of range of missiles and technology (Gilboy \& Heginbotham, 2012, p. 196).

In sum, as a result of continuous and active bids for building up its military force since the early 1990s, China currently enjoys military predominance over India. Specifically, the gap in national defense between China and India has even widened, and there is a seemingly formidable imbalance between these two countries' military capability. During the Cold War, even though India took a terrible beating in the border war with China in the 1960s, and confronted China's nuclear threat, India was ensured its security under Soviet military and nuclear umbrella, and therefore, it is reasonable to argue that India may have thought that the threat posed by China during that time could be overcome: There was no rise of China during the Cold War, but only after the Cold War ended.

\section{Implications for India's Security}

Then, what are the implications to India's security of China's military rise? Does India regard the rise of China as an opportunity to stabilize India's security, or as a threat that could inflict serious damage on its national security? Although there have been various steps of bilateral cooperation between these two countries, there are some factors which indicate that China's military build-up should be regarded as a significant threat to 
India's security: (1) China's frequent military activities in Tibet, a long border with India; (2) China's strengthened military posture around the Indian Ocean region, which has been considered as India's traditional backyard; and (3) China's active bids to establish close bilateral military relationship with neighboring countries.

China's Military Activities in Tibet. Since the 1990s, and specifically since the 2000s, China has strengthened its jurisdiction over Tibet for several reasons. First of all, economically, there are abundant natural resources there. Specifically, the amount of copper and iron ore in Tibet account for most of the reserves throughout the entire China. Considering that China has focused on its economic development and, thus, needs enormous amounts of mineral resources, a stable control over Tibet must be essential to China (Kaplan, 2010, p. 26). Second, politically, there have been various anti-government demonstrations and secessionist movements by Tibetans, and the central government of China has shown its sensitivity about this issue. Moreover, since these secessionist movements in Tibet could lead to a domino effect among other minority ethnic groups that have carried out separatist movements, China has made significant efforts to consolidate its jurisdiction over Tibet. Third, China's efforts to strengthen its leverage on this area could be interpreted as an attempt to show its firm will to stabilize sovereignty over disputed areas. Recently, in the wake of its remarkable economic and military capability, China has taken more aggressive and assertive actions toward the disputed areas, such as the South China Sea, and this aggressive approach of China could also be reflected in border issues with India. Specifically, in this regard, China's Tibetan policy could cause a significant concern for India, given that Tibet is located around a long border between these two countries.

In reality, China has enhanced its jurisdiction and military capability over Tibet in two ways (Sahgal, 2012, pp. 279-281). First, it has built various military-related facilities in the Tibet area. China, for instance, has constructed various railroads from lowlands to Tibet, including Colmud-Lhasa rail line which enables China to deploy as many as 12 PLA divisions over a four-week period. Furthermore, it is also upgrading China's net-centric warfare capability in Tibet, designed to enhance its cyber-warfare ability there. In addition, China has constructed five operational airfields around Tibet, and upgraded landing grounds there, which also helps China to enhance its military projection and its air power around Tibet. Second, China has increased the level and the frequency of military exercises in Tibet, as well as supplied military hardware. In 2011, for example, China conducted grand scale joint military exercise, including a large number of specialized mountain troops, China's fourth generation fighters (J-10), and rocket fire. Specifically, this military exercise was conducted along the Indian border, indicating that China may be preparing for integrated military operations in order to deal with the potential border crisis with India. Besides, one India defense analyst argues that China may have been upgrading its nuclear and ballistic missiles around Tibet to target India (Sahgal, 2012, p. 281).

After all, although China and India have held a series of regular meetings over their border issue, China has also tried to strengthen its military capability, and increased the frequency of its military exercises around its border area with India, which heightens the tension between China and India. And, considering that territory constitutes a core national interest, that Tibet shares a long border line with India, and that the border issue between China and India has not been resolved, China's recent military development around Tibet must pose a serious threat to India's national security.

China's Military Activities in the Indian Ocean Region. China's ambition to expand its military influences in the Indian Ocean region is more obvious than in Tibet. Specifically with its recent development of naval power, which empowers China to significantly enhance its naval projection capability, China now shows 
its ambition to strengthen its naval influences around Indian Ocean for three reasons: First, alongside the South China Sea, Indian Ocean has become an essential sea lane to China in terms of its energy security. In other words, since most of the oil that China imports is transported from the Middle East via Indian Ocean, it is one of the most important routes to China. Second, in response to the advanced US-India bilateral relationship, which China sees as a part of the US containment policy against itself, China is trying to check this relationship by enhancing its profile in the Indian Ocean (Lee, 2002, p. 553; Pant, 2009, pp. 287-288). Finally, China is strengthening its naval leverage there, arguably to be a real regional superpower in Asia. That is to say, beyond its backyard, the South China Sea, China may try to consolidate its regional hegemonic position by dominating other waters in Asia. For these reasons, China recently has conducted a series of joint military exercises either alone or multilaterally, and has built naval bases in littorals. In 2009, for example, China deployed its naval power to Indian Ocean to participate in Peace Mission 2009, a military exercise under the Shanghai Cooperation Organization (Cole, 2010, p. 136), and most recently, in 2014, it conducted unannounced naval exercise in Indian Ocean, including training for electronic war there (Brissenden, 2014).

For India, Indian Ocean is also very important. Traditionally and geographically, Indian Ocean has been regarded as India's front and back yard, and more importantly, this ocean plays a significant role in India's economic development. In other words, India, which heavily relies on free trade with foreign countries, transports more than $90 \%$ of its commercial goods through Indian Ocean (Pant, 2009, p. 282). Considering its geographical and economic importance, therefore, if China increases its profile in Indian Ocean with its relatively more powerful military capability than India's, and consequently, India's freedom around this water is disturbed, India could suffer greatly in terms not only of its economic development but also of its national security. Indeed, in his speech in 2009, Admiral Suresh Mehta, the then outgoing Indian Navy chief of staff, expressed significant concerns about China's growing military influences on the Indian Ocean, arguing that India must reduce the military gap between these two countries and "counter the growing Chinese footprint in the Indian Ocean Region" (Winner, 2013, p. 114). After all, China's recent frequent military activities in Tibet and Indian Ocean naturally cause India to be concerned about China's increasing profile around these areas, and therefore, lead to a traditional security dilemma between China and India.

China's Boosting Ties with Asian Countries. With its enhanced military power, China has tried to establish close military relationship with its Asian neighbors. Similar to rationales of China's approach toward Indian Ocean, China tries to stabilize transportation routes of commerce and imported natural resources, by establishing close relationship with South and Southeast Asian countries. That is to say, through its consolidation of relationship with some Asian countries, China has built various sea ports and expressways, and these enable China to secure various transportation routes. Moreover, strategically, China's establishment of these relationship may be motivated by the necessity of checking the US influences on Asia. That is to say, to counterbalance the US approach to Asian countries, China may try to form close relationship with its neighbors. Another reason for this policy, furthermore, could be China's efforts to reassure its neighbors regarding their concerns about rising China. Indeed, there has been a shared sense of threat about the rise of China among some Asian countries. Therefore, Saunders (2008) suggested that China's bids to establish close ties with these countries could be regarded as its reassurance campaign, which aims at demonstrating that its rise will not be threatening, but will be peaceful to other regional actors (p. 131).

Based on these rationales, since the 1990s, China has adopted its "string of pearls" policy, aimed at cementing its relationship with countries around the South China Sea and the Indian Ocean. This so-called 
"string of pearls" policy is designed to construct Chinese naval bases and facilities along with littoral countries of Indian Ocean, and thus, to expand China's influence there. According to Brewster (2011), India considers that China's "string of pearls" strategy is designed to constrain India, casting doubts on China's intention (pp. 236-237). Mohan Malik (2006), an Indian scholar, also argued that by gaining access to South Asian countries, "Beijing also wants to make a point on the limits of Indian power". In addition, China's approach to Pakistan and Bangladesh, both of which have assumed a hostile attitude against India for a long time, is worthy of notice. Recently, China has provided Pakistani navy with its advanced military technology and sold cutting-edge submarines, as well as built naval port in Gwadar, Pakistan (Brewster, 2011, p 182). As Pant articulated (2011), though Pakistani naval power alone does not pose any threats to India's national security, "the combination of Chinese and Pakistani naval forces could indeed be formidable for India to counter" (p. 111). In addition, China has offered its nuclear and missile technology in earnest to Pakistan since the 1990s (Lee, 2002, p. 555).

With regard to Bangladesh, China also obtained access right to Chittagong port and built another container port there. China also has increasingly sold various weapons to Bangladesh, which have eventually accounted for $80 \%$ of Bangladesh's military purchases since 2005 (Schaffer, 2011, p. 306). Considering that Bangladesh is geographically a starting point of India's "Look East" policy, China's approach and extension of its influences on Bangladesh could restrict India's policy implementation in the future. After all, China has successfully established close ties with its South Asian neighbors in general, Pakistan and Bangladesh in particular, since the 1990s. Furthermore, by improving close relationship with Pakistan, China's containing strategy targeting India has been regarded as success (Pant, 2009, p. 290). Considering the historical antagonism that India has against Pakistan and Bangladesh, and geographical locations of these countries, China's boosting ties with Pakistan and Bangladesh may sound the alarm to India.

In sum, China's military strengthening in Tibet, military foray in the Indian Ocean, and improvement of bilateral relationship with its neighbors cannot help becoming major concerns to India's national security. India is naturally worried about its powerful neighbor, China, because India does not know China's intentions, and has to worry about being attacked by more powerful China. Indeed, concerns about the rise of China have become part of the public discourse among Indians. During talks with President Obama in 2015, the Indian Prime Minister, Modi, expressed concerns about China's recent growing influences on the region, and suggested establishing a security network including the US, Japan, Australia, and India, to deal with growing Chinese impacts on the region (Baker \& Harry, 2015). Furthermore, at the conference held by the Asian New Zealand Foundation in 2014, many Indian delegates also viewed China's recent activities in Asia with suspicion, stating that "China might be attempting to encircle India through military, trade and diplomatic means” (Pearse-Smith, 2014).

\section{India's Balancing Strategy}

Confronting the rise of China since the 1990s, India has adopted counterbalancing policy to reduce its security concerns: military modernization, development of nuclear weapons program, both of which are regarded as internal balancing, and establishment of close bilateral relations with regional countries, which is considered as external balancing. To take counterpoise against China, India's balancing strategy has been explicit during the post-Cold War era, when compared to India's military build-up and foreign policy during the Cold War era. 


\section{India's Internal Balancing}

According to neorealists, internal balancing represents a country's building up of its national strength on its own, and this mainly includes military build-up. India, for instance, has been modernizing its army, navy, and air forces, as well as developing its nuclear-related components.

India's Military Modernization. India's military modernization since the 1990s has been remarkable, and focused on improving its deterrent power and projection capability. To enhance its naval power, in the next decade, India aims to launch total of 140-150 battleships, to have at least two aircraft carrier battle groups, and to acquire fourth-generation fighters fit for these aircraft carriers. Indeed, India plans to enter into service two domestically built aircraft carriers (INS Vikrant and INS Vishal) in 2015 and 2018, respectively. Moreover, to restrict China's growing military influence on Indian Ocean, India developed its first indigenous nuclear submarines in 2009, and has developed its indigenous submarine program, designed to induct five more Advanced Technology Vehicle nuclear submarines (Ladwig III, 2010; Pant, 2009). In addition, as one strategy to strengthen naval projection capability, to counter China's growing influences on India Ocean, and therefore, to achieve its predominance over this water, India has been building various state-of-the-art military facilities on Indian Ocean islands, since the mid-1990s (Brewster, 2011, p.239).

In addition, India has worked hard to deal with imbalance between China's and India's land force around their border area, by implementing long-term army modernization policy: India recently equipped its mountain divisions with cutting-edge, ultra-light, and easily transportable arms. Moreover, it acquired American-built Landing Platform Dock, which greatly increases Indian army's transportation ability (Ladwig III, 2010, pp. 1179-1182; Sahgal, 2012, pp. 293-295).

Furthermore, India is also modernizing its air force, which currently operates various fighters. Notably, Indian air force has made efforts to induct long-range strike aircraft, and to buy a large number of top-of-the-line fighter-bomber aircraft, all of which could significantly enhance Indian air force's ability to strike target across its neighborhood. Meanwhile, India is decommissioning some of its old-fashioned combat aircrafts, such as MiG-23. To widen range of air force operation, India is trying to acquire more effective and advanced aerial tankers (Gilboy \& Heginbotham, 2012, pp. 190-195; Ladwig III, 2010, pp. 1176-1179).

Comparing to India's military build-up during the Cold-War era, when there was no rise of China, the current military modernization of India during the post-Cold War shows two differences. First of all, the target of modernization has changed. During the Cold War, India's military modernization targeted mainly its northwestern neighbor, Pakistan, and domestic insurgent groups. For example, although there were 11 divisions deployed to the border area with China, just after the border war broke out in 1962, these China-oriented divisions were reallocated to western border area, including Kashmir during the 1980s, and reassigned the task of countering Pakistan. Moreover, the Eighth mountain division, which had defended India's northeastern border area against China, was also reallocated to Northern Command for counterinsurgency. In addition, pursuing its land force modernization during the 1980s, India repeatedly conducted a series of military exercises along its western border area. For one military exercise during that time, designed to test its land force capability vis-à-vis Pakistan, India employed as many as 400,000 troops around the Indo-Pakistan border area, and checked its logistic ability (Cohen \& Dasgupta, 2010, pp. 54-57, 80).

Furthermore, the current military modernization of India aims to target mostly China. In response to China's military build-up around Tibet, India is embarking on army modernization: India deployed two new 
specialized infantry mountain divisions, consisting of 35,000 soldiers, and one artillery brigade to Sino-India border area, in order to strengthen its deterrent power against China (Pant, 2011, p. 111). Moreover, in response to China's growing threat along the Sino-India border area, India successfully tested long-range ballistic missiles (3,500-km-range Agni 4 and 5,500-km-range Agni 5), two of which can strike entire eastern coast of China (Sahgal, 2012, p. 281). That is, given Pakistan's geographical closeness to India and a range of Pakistani territory, India's further development of ballistic missile program during 2000s may not be aiming mostly at Pakistan, but at China.

Second, as a pattern of military modernization, India has increasingly focused more on naval modernization than in the past, arguably targeting China's growing naval leverage in the Indian Ocean. While Indian army received most of the attention during the Cold War era, because of the ground-war threats (Cohen \& Dasgupta, 2010, p. 75), Indians now making significant efforts to enhance its naval power and projection ability, as mentioned above. Considering that Indian naval power already has precedence over Pakistani in both quantitative and qualitative terms, it is reasonable to think that India's recent focus on naval modernization may be understood as a counterbalancing against China's naval power, which has increased its influences on Indian Ocean. Indeed, as publicly announced by the Ministry of Defense in 2004, India's maritime doctrine focuses a lot on potential threats posed by Chinese naval power in the Indian Ocean (Zhao, 2008, p. 178), and this implies that India definitely has enormous concern about China's naval power, and therefore, has explicit intention to counter China's growing naval capability, by modernizing its own sea power.

In sum, unlike India's past military build-up, its current military modernization could be mainly motivated by the rise of China, which leads India to strengthen its ground power around Sino-India border area, to develop long-range intercontinental ballistic missiles which can reach entire eastern coast of China, and to focus on naval modernization. In the past, on the one hand, China was not India's main target of military build-up, since Himalayas may have acted as a geographical barrier and China during that time did not have strong airlifting capability and naval power. Having achieved rapid military build-up and established superiority over other Asian countries since the early 1990s, on the other hand, China has increased its military activities around Tibet and Indian Ocean. And, these activities subsequently have posed a major threat to India's national security. Therefore, India's current active bids to modernize its military force could be understood as one part of its counterbalancing China.

Nuclear Weapons Program. Alongside its military modernization efforts, India's development of nuclear weapons program also could be regarded as one part of balancing behavior against China. India's nuclear weapons program started during the Cold War era, in response to China's growing threats. In other words, India experienced a humiliating defeat in the Sino-India border war in 1962, was threatened by China's intervention in the Indo-Pakistani war in 1965, and failed to receive security guarantee from other superpowers, all of which made India decide to embark on its nuclear weapons program (Ganguly \& Kapur, 2010, p. 8). This implies that India's nuclear weapons program was motivated by its security concern, mainly regarding China and Pakistan. However, even though India has continuously pursued its nuclear weapons program, and therefore, acquired enough technology to manufacture a bomb, it eventually did not cross the threshold into a nuclear weapons state, not getting involved in making nuclear weapons in earnest (Gilboy \& Heginbotham, 2012, p. 59). In other words, although India developed its nuclear weapons program during the Cold War, it maintained long-standing policy of nuclear ambiguity, and thus, did not make actual nuclear weapons until the 1990s. In this regard, some reasons why India eventually did not make nuclear weapons during the Cold War could be 
suggested. First, during that time, India had close relationship with the Soviet Union, and therefore, it enjoyed security guarantee from the Soviet nuclear umbrella. Second, the Himalayan Mountains could function as a geographical barrier between China and India. Third, bipolar system actually had significant impact on regional order in Asia during that day. Therefore, although China and Pakistan posed a significant threat to India's national security, which may have led India to initiate its nuclear weapons program, India may not have considered the threat from China and Pakistan as insurmountable, and thus, may have decided not to make actual weapons.

However, with the end of the Cold War, circumstances dramatically changed. During the 1990s, for example, the Nonproliferation Treaty (NPT) was strengthened with subsequent agreements, and establishment of the Comprehensive Test Ban Treaty (CTBT), which India nominally supported, was about to bear fruit. Moreover, India lost its security guarantor, the Soviet Union, and China's full-scale military and economic rise during that time became a major concern to India. In addition, China has accelerated development of its nuclear weapons program and associated missile delivery system since the mid-1980s, specifically devaluing the function of geographical barrier that the Himalayas had (Lewis, 2013, pp. 71-72). Facing this circumstance, India may have thought that, if it did not make nuclear weapons until the CTBT entered into force, it could be left behind China, which already possessed nuclear weapons in the 1990s, and showed its dramatic military and economic rise, in security terms, and therefore, India should always be concerned about China's rise and its future threats. Furthermore, if India's nuclear weapons program was restricted, as a result of the CTBT, India may have thought that it could not effectively and practically deter the threat of China.

Indeed, India dismissed its ambiguous position to make nuclear weapons, and successfully conducted its nuclear weapons test in 1998, which made India a true nuclear weapons state since then. That is to say, while India had remained as a latent nuclear weapons state during the Cold War, in spite of its continuous nuclear weapons program, India finally built its nuclear weapons in 1998, and has maintained nuclear weapons state position since then. Furthermore, specifically since the mid-2000s, India expedited its nuclear weapons program and intercontinental ballistic missile program. Currently, India's fission weapons are capable of generating the range of 12-15 kilotons, and it also has raised the number of its nuclear warhead stockpiles from 70 in 2010 to 100 in 2013 (Tellis, Denmark, \& Tanner, 2013, p. 314). Moreover, India has successfully developed a series of long-range ballistic missiles, which can deliver nuclear warheads. For instance, in the 2000s, India completed development of two ballistic missiles, Agni 3 and Agni 4, which could strike the entire east coast of China, and, in the early 2010s, India has successfully developed and deployed the 5,000-km Agni 5, which can cover the entire Chinese territory. In addition, India aims to develop and allocate at least three nuclear-powered ballistic missile submarines by the late 2010s to enhance its sea-base second-strike capability and arguably obtain sea-base nuclear deterrent against China (Kampani, 2013, pp. 110-114).

Of course, there could be various factors that may have influenced India's decision to become a true nuclear weapons state, such as India's aspiration to obtain national prestige, or Indian leaders' national identity (Hymans, 2006, pp. 171-203). However, as Ganguly (1999) pointed out, India's current nuclear armaments are obviously connected to India's security concern. In other words, there are some factors which support the argument that, in order to understand motivation of India's nuclear weapons program, its security concern should not be taken lightly: China's dramatic economic and military rise widening the gap between these two countries' national power, unresolved territorial dispute between China and India, China' active military foray in Tibet and Indian Ocean, China's recent active development of its nuclear weapons program and delivery 
missile system, Sino-Pakistani nuclear cooperation specifically since the 1990s, and absence of the Soviet Union's security guarantee. In sum, considering these factors, India's deep-rooted distrust of, and security concern posed by China, could be one of the most crucial factors that drove India to make nuclear weapons, and therefore, it is reasonable to think that India's nuclear armaments could be interpreted as one part of effective internal balancing acts, designed to counter the rise of China.

\section{India's External Balancing}

Alongside its internal balancing behaviors, military modernization and pursuit of nuclear weapons program, India is also adopting active external balancing policy, by establishing close relationship with other regional powers. In other words, even though India has made significant efforts to enhance its national power in an internal way, there are various limitations to its development, which eventually cause a widening gap between China's and India's national power. And therefore, India's search for external supporters is an effective and complementary way to balance against China. Indeed, specifically after the Cold War ended, India significantly changed its traditional foreign doctrine from nonalignment policy to more active approach to its neighbors, such as "Look East" policy.

In this regard, one of the most notable shifts of India's foreign policy could be found in the bilateral relationship between India and the US. During the Cold War, the Indo-US relationship had been practically frozen. For India, which had close relationship with the Soviet Union in spite of its nonalignment policy, the US was recognized as an expansionist country. Furthermore, as the Sino-US and Pakistani-US relationship became closer in the 1970s, India had a doubt over these relationship. Meanwhile, the US also regarded India as a close friend of the Soviet Union. Moreover, during the Cold War, these two countries did not have close economic, strategic, and cultural ties with each other, and subsequently, there was no reason for them to establish close relationship (Ganguly, 2008, pp. 155-157). However, as international circumstances changed in the wake of collapse of the Soviet Union in the early 1990s, India dismissed its oppositional policy against the US, and tried to establish close relationship. That is to say, after the Soviet Union broke down, India realized that Russia would not be a reliable supporter, and that, instead, the US could help India to fill a security vacuum in Asia, and balance against China's rising power (Kapur \& Ganguly, 2007, p. 647). From the US perspective, India has become an important partner of the US containment policy against China. As a result, the Indo-US relationship has flourished since the 1990s. According to Ganguly (2008), for instance, both countries have forged a comprehensive security partnership with each other, and exchanged defense cooperation programs, such as civilian nuclear technology and ballistic missile defense (p. 156). Moreover, he also suggested that these two countries have conducted a series of military exercises specifically during the 2000 s, establishing stable strategic partnership (Ganguly, 2008, p. 157).

India also changed its attitude toward ASEAN countries, by adopting its "Look East" policy in the early 1990s. During the Cold War, the relationship between India and ASEAN countries were also marginal, because India saw ASEAN countries as stooges of the US, and some ASEAN countries threw discredit on India's support for Vietnam's invasion of Cambodia (Ganguly, 2008, p. 159). However, the fact that China has aggressively expanded its leverage on Southeast Asian countries with its growing economic power, and that India adopted its openness and reform policy in the 1990s, led India to seek establishment of close relationship with ASEAN countries. Consequently, India adopted its "Look East" policy in order to forge close relationship with its Southeastern neighbors. Both India and ASEAN countries have not only strengthened their economic 
ties, but also cooperated in various areas, such as tourism, education, and culture, by initiating the "Mekong-Ganges River Cooperation Project", including India and five ASEAN countries (Vietnam, Laos, Cambodia, Myanmar, and Thailand), and the Bangladesh, India, Myanmar, Sri Lanka, Thailand Economic Cooperation (the BIMSTEC) (Zhao, 2007, pp. 131-132).

More importantly, India has recently improved its strategic and military ties with these ASEAN countries. During the 2000s, for instance, India and ASEAN countries have actively cooperated in order to deal with regional terrorism and piracy (Yahya, 2003, pp. 89-91). In terms of Indo-Indonesia relationship, India concluded agreements on defense cooperation with Indonesia in 2001, conducted joint naval patrols in the eastern Indian Ocean, and declared a "New Strategic Partnership" (Brewster, 2011, p. 232). In addition, India provides Indonesia with its defense technology and training assistance, transforming this bilateral relationship into comprehensive strategic one. With regard to Vietnam, since 2000s, India has regularly deployed its navy to Vietnamese naval port, and conducted high-profile joint naval exercises with Vietnam in the South China Sea (Scott, 2012, p. 1030; Zhao, 2007, p. 131). Specifically, India's establishment of close strategic and military relationship with ASEAN countries indicates that, as Zhao (2007) and Pant (2011) observed, India's "Look East" policy, which was initially designed to improve economic ties with its Southeastern neighbors, has become a more security-oriented policy. Furthermore, India's joint naval exercises and military activities with some ASEAN countries around the South China Sea also show that India's active bids to establish close military ties with them could aim to balance against China, considering that the South China Sea has been regarded as China's backyard.

India's recent approach to Northeast Asian countries is also remarkable. Even though both India and Japan hesitated to establish a relationship with each other during the Cold War, since India saw Japan as a satellite country of the US and Japan regarded India as pro-Soviet country, the bilateral relationship between these two countries has dramatically improved since the 1990s, especially during the 2000s (Ghosh, 2008). Moreover, after enjoying favorable economic cooperation between these two countries, the bilateral relationship has now become strategy-focused one. According to Ghosh (2008), for instance, India and Japan agreed to hold annual comprehensive security dialogues in 2006, and have conducted joint naval exercises since then (pp. 287-292). Above all, the most significant motivation to improve the bilateral relationship between India and Japan may be these two countries' shared concerns about the rise of China. That is to say, China's growing naval power and strengthening of its naval influence on the East/South China Sea and Indian Ocean could be considered a significant security threat to both Japan and India. Moreover, considering that both countries have competed with China over various issues, including serious territorial disputes, and therefore, have a sense of competitiveness toward and distrust of China, the recent improvement in Indo-Japan relationship may have been motivated mainly by these two countries' concern about the rise of China.

Finally, in terms of Indo-South Korea relationship, through which there was little political and economic interaction between them during the Cold War, India has also tried to establish close ties with South Korea since the 1990s (Brewster, 2010). As an extended partner of "Look East" policy, India boosted its economic relationship with South Korea, increasing the volume of bilateral trade from 600 million dollars in 1993 to about 15.6 billion dollars in 2008 (Brewster, 2010, p. 410). Since the mid-1990s, moreover, South Korea has become one of the largest foreign investors in India, and a lot of South Korean companies entered the Indian market. Strategically, both India and South Korea have eagerly tried to improve their bilateral relationship, and this includes: initiation of annual security dialogues, cooperation in the joint development defense technology, 
improvement of defense industry cooperation, and agreement to conduct joint coast guard exercises (Brewster, 2010, pp. 417-418).

In sum, India's external balancing behavior during the post-Cold War era shows a significant difference from its bilateral relationship with other regional countries during the Cold War: Unlike during the Cold War era, India shows its active and ambitious bids to establish close ties with them. And, here, two characteristics of India's current external balancing are observed, which indicate that India's current external balancing is possibly designed to balance against rising China. First of all, India's partners mentioned above share common security concern about the rise of China. The US has paid sharp attention to China's rise in Asia, because China could become a true revisionist country on the international scene. Furthermore, Japan, which has competed with China for regional hegemony in Asia, conflicts with China over territorial issue (Senkaku/Diaoyu Islands). In addition, South Korea is also sensitive to China's growing power because of their overlapping interests in the Yellow Sea, China's growing role in North Korean-related issues, and South Korea's relation with the US. Moreover, ASEAN countries, specifically Vietnam, the Philippines, and Indonesia, have experienced fierce maritime territorial disputes over the South China Sea in general, and the Spratly Islands in particular, and therefore, have worried about the fact that China has rapidly strengthened its leverage over Southeast Asia. After all, considering that these countries compete with China over various areas, and are anxious about China's rise, India's active approach to these countries could be interpreted as a balancing behavior, aimed at cooperatively tackling the rise of China.

Secondly, India's bilateral relationship are not limited to economic ties any more, but have become comprehensive security-focused ones. In other words, as stated above, India has come to cooperate with the US, ASEAN countries, Japan, and South Korea, in terms not only of economic or non-security issues, but also of strategic and military ones. As a result, by conducting various military exercises in the South China Sea with ASEAN countries, specifically Vietnam, India shows its proactive attempts to counter China's growing naval influences in China's backyard. Moreover, India's recent improvement of strategic relationship with some Northeast Asian countries also implies that India's approach to these countries is not motivated merely by economic reasons or globalization, but arguably by India's security calculations, considering the fact that India could strategically constrain China, by establishing close ties with South Korea and Japan. And given that India's close strategic relationship with above-mentioned countries could geographically balance against China's recent active closeness to South Asian countries, India's primary purpose for these bilateral relationship becomes obvious: balancing against China.

\section{Conclusion}

How has India perceived the rise of China, and what has been India's strategy toward China? As discussed through this study, India since the 1990s has seen the rise of China as a significant threat to its national security, and therefore, its behavior dealing with China could be characterized as a balancing act. In other words, in the wake of its outstanding economic and military growth, China has widened the gap between these two countries' power, and is now enjoying predominance over India, in both economic and military terms. China aggressively and actively strengthened its military posture in the Sino-India border area, and increasingly conducted its naval activities around Indian Ocean. Moreover, by providing outstanding military-related technology to some South Asian countries, specifically Pakistan and Bangladesh, China has enhanced its close relationship with these countries. At the same time, these actions of China may be seen as a significant threat to India, because the 
stage of actions overlaps India's core area of interests, and India also has a deep-rooted distrust of China's intentions. Therefore, India cannot help but worry that it could be threatened or even attacked by a powerful China in the future. To effectively deal with the threat posed by a rising China and to stabilize its security, India has adopted a policy of balancing against China. The implementation of this policy has involved modernizing its military force, pursuing its nuclear weapons program, and establishing close ties with other regional countries.

Finally, India's balancing behavior has an important policy implication. Most of all, it should be noted that, India's recent active counterbalancing strategy could cause side effects. That is to say, India's active military modernization could create doubt for China. And, India's active bids to establish closer relationship with other regional actors could be seen as containment policy designed to counter China. After all, these internal and external balancing behaviors of India, in turn, could prompt China to take its own counterbalancing measures, which could step up the arms race between these two countries, and intensify competition over other regional countries. Therefore, India's policy makers need to refrain from carrying out its too blatant counterbalancing strategy against China, and also need to take active and substantive measures with China to reduce tension between them.

\section{References}

Baker, P., \& Harris, G. (2015, January 26). US and India share sense of unease over China. New York Times. Retrieved August 20, 2015, from http://www.nytimes.com/2015/01/27/world/us-and-india-share-sense-of-unease-over-china.html?_r=2

Brewster, D. (2010). India's developing relationship with South Korea: A useful friend in East Asia. Asian Survey,50(2), $402-425$.

Brewster, D. (2011). The relationship between India and Indonesia. Asian Survey, 51(2), 221-244.

Brissenden, M. (2014, February 13). China conducts military exercises in Indian Ocean. ABC News. Retrieved June 10, 2015, from http://www.abc.net.au/lateline/content/2013/s3944471.htm

Cohen, S. P., \& Dasgupta, S. (2010). Arming without aiming_India's military modernization. Washington, DC: The Brookings Institution.

Cole, B. D. (2010). The great wall at sea. Annapolis, MD: Naval Institute Press.

Erickson, A. S. (2012). China's modernization of its naval and air power capabilities. In A. J. Tellis \& T. Tanner (Eds.), China's military challenge (pp. 61-125). Seattle, WA: The National Bureau of Asian Research.

Ganguly, S. (1999). India's pathway to Pokhran II: The prospects and sources of New Delhi's nuclear weapons program. International Security, 23(4), 148-177.

Ganguly, S. (2008). The rise of India in Asia. In D. Shambaugh \& M. Yahuda (Eds.), International relations of Asia (pp. 150-169). Lanham, MD: Rowman \& Littlefield.

Ganguly, S., \& Kapur, P. (2010). India, Pakistan, and the bomb. New York, NY: Columbia University Press.

Ghosh, M. (2008). India and Japan's growing synergy: From a political to a strategic focus. Asian Survey, 48(2), $282-302$.

Gilboy, G. J., \& Heginbotham, E. (2012). Chinese and Indian strategic behavior. New York, NY: Cambridge University Press.

Hymans, J. E. C. (2006). The psychology of nuclear proliferation. New York, NY: Cambridge University Press.

Kampani, G. (2013). India: The challenges of nuclear operationalization and strategic stability. In A. J. Tellis, A. M. Denmark \& T. Tanner (Eds.), Asia in the second nuclear age (pp. 99-128). Seattle, WA: The National Bureau of Asian Research.

Kaplan, R. D. (2010). The geography of Chinese power: How far can Beijing reach on land and at sea? Foreign Affairs, 89(3), 22-41.

Kapur, S. P., \& Ganguly, S. (2007). The transformation of US-India relations: An explanation for the rapprochement and prospects for the future. Asian Survey, 47(4), 642-656.

Ladwig III, W. C. (2010). India and military power projection: Will the land of Gandhi become a conventional great power? Asian Survey, 50(6), 1162-1183.

Lee, J. (2002). China's expanding maritime ambitions in the Western Pacific and the Indian Ocean. Contemporary Southeast Asia, 24(3), 549-568. 
Lewis, J. (2013). China's nuclear modernization: Surprise, restraint, and uncertainty. In A. J. Tellis, A. M. Denmark \& T. Tanner (Eds.), Asia in the second nuclear age (pp. 67-96). Seattle, WA: The National Bureau of Asian Research.

Malik, M. (2006). The Indian Ocean Region: China's strategy of containing India. Retrieved August 20, 2015, from http://tamilnation.co/intframe/060206china_india.htm

Mearsheimer, J. J. (2001). The tragedy of great power politics. New York, NY: W. W. Norton.

Pant, H. V. (2009). India in the Indian Ocean: Growing mismatch between ambitions and capabilities. Pacific Affairs, 82(2), 279-297.

Pant, H. V. (2011). India comes to terms with a rising China. In A. J. Tellis, T. Tanner\& J. Keough (Eds.), Asia responds to its rising powers (pp. 101-128). Seattle, WA: The National Bureau of Asian Research.

Pearse-Smith, S. (2014). Prime Minister Modi and China's rise dominate talks with Indian think tanks. Retrieved August 21, 2015, from http://asianz.org.nz/bulletin/prime-minister-modi-and-chinas-rise-dominate-talks-indian-think-tanks

Rahman, C., \& Tsamenyi, M. (2010). A strategic perspective on security and naval issues in the South China Sea. Ocean Development \& International Law, 41, 315-333.

Sahgal, A. (2012). China's military modernization: Responses from India. In A. J. Tellis \& T. Tanner (Eds.), China's military challenge (pp. 277-305). Seattle, WA: The National Bureau of Asian Research.

Saunders, P. C. (2008). China's role in Asia. In D. Shambaugh \& M. Yahuda (Eds.),International relations of Asia (pp. 127-149). Lanham, MD: Rowman \& Littlefield.

Schaffer, T. C. (2011). India next door, China over the horizon. In A. J. Tellis, T. Tanner \& J. Keough (Eds.), Asia responds to its rising powers (pp. 285-310). Seattle, WA: The National Bureau of Asian Research.

Scott, D. (2012). Conflict irresolution in the South China Sea. Asian Survey, 52(6), 1019-1042.

Stockholm International Peace Research Institute. (2015). SIPRI military expenditure database [Data File]. Retrieved April 21, 2015, from http://www.sipri.org/research/armaments/milex/milex_database

Stokes, M. A. (2012). The second artillery force and the future of long-range precision strike. In A. J. Tellis \& T. Tanner (Ed.), China's military challenge (pp. 127-160). Seattle, WA: The National Bureau of Asian Research.

Tellis, A. (2011). The United States and Asia's rising giants. In A. J. Tellis, T. Tanner \& J. Keough (Eds.), Asia responds to its rising powers (pp. 3-32). Seattle, WA: The National Bureau of Asian Research.

Tellis, A. J., Denmark, A. M., \& Tanner, T. (Eds.). (2013). Asia in the second nuclear age. Seattle, WA: The National Bureau of Asian Research.

Tellis, A. J., \& Tanner, T. (Eds.). (2012). China's military challenge. Seattle, WA: The National Bureau of Asian Research.

Tellis, A. J., \& Wills, M. (Eds.). (2005). Military modernization in an era of uncertainty. Seattle, WA: The National Bureau of Asian Research.

Walt, S. M. (1987). The origins of alliances. Ithaca, NY: Cornell University Press.

Waltz, K. N. (1979). Theory of international politics. New York, NY: McGraw-Hill.

Winner, A. C. (2013). India: Dominance, balance, or predominance in the Indian Ocean? In J. Garofano \& A. J. Dew (Eds.), Deep currents and rising tides (pp. 111-135). Washington DC: Georgetown University Press.

Yahya, F. (2003). India and Southeast Asia: Revisited. Contemporary Southeast Asia, 25(1), 79-103.

Zhao, H. (2007). India and China: Rivals or partners in Southeast Asia? Contemporary Southeast Asia, 29(1), 121-142.

Zhao, H. (2008). China and India: Competing for good relations with Myanmar. The Journal of East Asian Affairs, 22(1), 175-194. 